\title{
Pengaruh Investasi Kelapa Sawit dan Tenaga Kerja terhadap PDRB pada Sub Sektor Perkebunan di Kabupaten Kutai Timur
}

\author{
Bagus Ariyanto, Fitriadi ${ }^{1}$, Akhmad Noor ${ }^{2}$ \\ Fakultas Ekonomi dan Bisnis Universitas Mulawarman, Indonesia \\ Email: bagusariyanto17@gmail.com
}

\begin{abstract}
Abstrak
Tujuan dari penelitian ini adalah untuk mengetahui pengaruh investasi kelapa sawit dan tenaga kerja terhadap produk domestik regional bruto sektor perkebunan di Kabupaten Kutai Timur dan mengetahui variabel yang berpengaruh dominan terhadap produk domestik regional bruto sektor perkebunan di Kabupaten Kutai Timur. Alat analisis yang digunakan dalam penelitian ini adalah Regresi Linier Berganda. Pengujian hipotesis menggunakan uji t dan uji F. Hasil analisis menunjukan investasi berpengaruh signifikan dan positif dan tenaga kerja berpengaruh positif terhadap pruduk domesti regional bruto sektor perkebunan.
\end{abstract}

Kata Kunci: Investasi, Tenaga kerja, Produk Domestik Regional Bruto

\section{The Effect of Palm Oil and Manpower Investment on PDRB In the Sub Sector of Plantation in East Kutai Regency}

\begin{abstract}
The purpose of this research is to know the influence of investment of palm oil and labor Force to gross domestic product of estate sector in East Kutai Regency and to know the dominant influence variable to gross domestic product of plantation sector in East Kutai Regency. The analysis tool used in this research is Multiple Linear Regression. Hypothesis testing using $t$ test and $\mathrm{F}$ test. The analysis shows that investment has a significant and positive effect and the work force has a positive effect on the gross domestic product in the plantation sector.
\end{abstract}

Keywords: Investment, Labor Force, Gross Regional Domestic Product 


\section{PENDAHULUAN}

Investasi merupakan kunci utama untuk mencapai peningkatan pertumbuhan ekonomi yang tercermin dari kemampuannya dalam meningkatkan laju pertumbuhan dan tingkat pendapatan. Semakin besar tingkat investasi suatu Negara akan semakin besar pula tingkat pertumbuhan ekonomi yang bisa dicapai. Menurut (Sukirno 2000:366), investasi adalah pengeluaran-pengeluaran untuk membeli barang-barang modal dan peralatan-peralatan produksi dengan tujuan untuk mengganti dan terutama menambah barang-barang modal dalam perekonomian yang akan digunakan untuk memproduksikan barang dan jasa di masa mendatang. Dalam ekonomi ada terminology There is no economic growth without investment. Pernyataan ini mengandung makna bahwa investasi mempunyai peranan penting dalam pertumbuhan ekonomi. meskipun memang investasi bukan satu-satunya komponen yang menentukan pertumbuhan ekonomi, namun investasi dianggap sebagai komponen terpenting yang menentukan pertumbuhan ekonomi dari suatu wilayah (Marsuki, 2006:1).

Pembangunan daerah merupakan bagian integral dari pebangunan nasional yang dilaksanakan berdasarkan pinsip otonomi daerah dan pengaturan sumberdaya nasional yang memberikan kesempatan bagi peningkatan demokrasi dan kinerja daerah untuk meningkatkan kesejahteraan masyarakat yang bebas kolusi, korupsi dan nepotisme. Penyelenggaraan pemerintah daerah sebagai sub sistem Negara dimaksudkan untuk meningkatkan daya guna dan hasil penyelenggaraan pemerintah dan pelayanan masyarakat. Sebagai daerah otonom, kabupaten/kota untuk bertindak sebagai motor sedangkan pemerintah provinsi sebagai koordinator mempunyai kewenangan dan tanggung jawab menyelenggarakan kepentingan masyarakat berdasarkan prinsip

Perkembangan perekonomian Kabupaten Kutai Timur tidak terlepas dari kontribusi sektorsektor ekonomi yang mendukungnya. Sektor perkebunan adalah salah satu sektor yang menunjukan pertumbuhan cukup signifikan, antara lain ditandai dengan semakin meningkatnya luas area produksi dan produktivitas. Komoditas yang paling banyak dikembangkan dalam perkebunan rakyat antara lain kakao, karet, lada, dan kelapa sawit. Secara khusus sektor perkebunan kelapa sawit menjadi primadona bagi masyarakat Kutai Timur, dan bahkan perkembangan kelapa sawit Kutai Timur diantara yang terbaik di wilayah Indonesia

Pertumbuhan ekonomi merupakan perkembangan kegiatan dalam perekonomian yang menyebabkan barang dan jasa yang diproduksi dalam masyarakat dan kemakmuran meningkat (Sukirno, 2000). Jadi pertumbuhan ekonomi mengukur prestasi dari perkembangan suatu perekonomian, Dari satu periode ke periode berikutnya kemampuan Negara untuk menghasilkan barang dan jasa akan meningkat. Kemampuan yang meningkat inI disebabkan oleh faktor faktor produksi baik dalam jumlah dan kualitasnnya. Investasi akan menambah barang modal dan teknologi yang digunakan juga makin berkembang. Disamping itu tenaga kerja bertambah sebagai akibat berkembangnya penduduk seiring dengan meningkatnya penidikan dan keterampilan mereka.

\section{METODE PENELITIAN}

Beberapa definisi operasional variabel dalam penelitian ini memiliki batasan sebagai berikut:

\section{Investasi (X1)}

Invetasi adalah realisasi penanaman modal dalam negeri (PMDN) dan modal asing (PMA) sektor perkebunan kelapa sawit di Kabupaten Kutai Timur yang dinyatakan dalam satuan Rupiah.

2. Tenaga Kerja (X2)

Tenaga Kerja adalah jumlah penduduk usia kerja (berusia 10 tahun ke atas) yang bekerja, yaitu melakukan kegiatan ekonomi yang menghasilkan barang/jasa secara kontinu paling sedikit satu jam dalam seminggu (BPS, 2006). Dinyatakan dalam satuan orang.

3. PDRB (Y)

PDRB adalah jumlah nilai tambah barang dan jasa yang dihasilkan dari seluruh kegiatan pekonomian diseluruh daerah dalam tahun tertentu atau perode tertentu dan biasanya satu tahun. PDRB kutai Timur menurut lapangan usaha dirinci menjadi 17 kategori lapangan usaha. Kategori ini mencakup lapangan usaha pertanian yang didalamnya terdiri dari sektor perkebunan.

Analisis data yang diperoleh untuk mengetahui seberapa besar pengaruh variabel-variabel bebas terhadap variabel terikat menggunakan model ekonometrika dengan meregresikan variabel- 
variabel yang ada dengan menggunakan metode OLS (Ordinary Least Square). Data-data yang digunakan, dianalisis secara kuantitatif dengan menggunakan analisis statistik yaitu persamaan regresi linear berganda. Variabel independen yang mempengaruhi variabel dependen dinyatakan dalam fungsi sebagai berikut:

$\mathrm{Y}=\mathrm{f}\left(\mathrm{X}_{1}, \mathrm{X}_{2}\right)$

Kemudian fungsi tersebut ditransformasikan menggunakan logaritma natural dan selanjutnya kedalam model persamaan linear berganda (multiple regression) dengan spesifikasi model sebagai berikut:

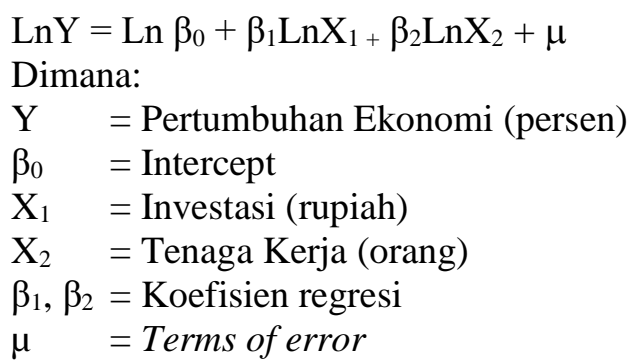

\section{HASIL DAN PEMBAHASAN}

Berdasarkan data yang di peroleh dari badan pusat statistik (BPS), maka akan dilakukan analisis terhadap data-data tersebut. Dalam penelitian ini terdapat dua variabel yaitu investasi (X1), Tenaga Kerja (X2) dan PDRB (Y), dimana investasi dan tenaga kerja sebagai variabel bebas dan PDRB sebagai variabel tidak bebas.

\section{Korelasi (R) dan Determinasi $\left(\mathbf{R}^{2}\right)$}

Besarnya korelasi antara variabel independent yang terdiri dari $\mathrm{X}_{1}$ Investasi, $\mathrm{X}_{2}$ Tenaga Kerja, terhadap variabel dependen Y PDRB Kabupaten Kutai Timur dapat dilihat pada tabel model summary berikut:

Tabel 4.5. Analisis Koefisien Determinasi

Model Summary

\begin{tabular}{|c|c|c|c|c|c|c|c|c|c|}
\hline \multirow[t]{2}{*}{ Model } & \multirow[t]{2}{*}{$\mathrm{R}$} & \multirow{2}{*}{$\begin{array}{c}\mathrm{R} \\
\text { Square }\end{array}$} & \multirow{2}{*}{$\begin{array}{l}\text { Adjusted R } \\
\text { Square }\end{array}$} & \multirow{2}{*}{$\begin{array}{l}\text { Std. Error } \\
\text { of the } \\
\text { Estimate }\end{array}$} & \multicolumn{5}{|c|}{ Change Statistics } \\
\hline & & & & & $\begin{array}{l}\text { R Square } \\
\text { Change }\end{array}$ & $\begin{array}{c}\mathrm{F} \\
\text { Change }\end{array}$ & df1 & $\mathrm{df} 2$ & $\begin{array}{c}\text { Sig. F } \\
\text { Change }\end{array}$ \\
\hline 1 &, $812^{\mathrm{a}}$ & 659 & ,602 & ,31471 & 659 & 11,604 & 2 & 12 & ,002 \\
\hline
\end{tabular}

Dari tabel 4.5 dapat dijelaskan bahwa nilai $\mathrm{R}$ atau korelasi hubungan antara variabel independen yang terdiri dari $\mathrm{X}_{1}$ Investasi, $\mathrm{X}_{2}$ Tenaga Kerja terhadap variabel dependen $\mathrm{Y}$ PDRB sebesar 0,812 atau sebesar $81,2 \%$. Hubungan antara variabel independen dan variabel dependen dalam penelitian ini menunjukan hubungan yang sangat kuat karena berada pada level $81,2 \%$. Nilai $\mathrm{R}^{2}$ atau determinasi sebesar 0,659 atau 65,9\% menunjukan bahwa pengaruh variabel independen yang terdiri $\mathrm{X}_{1}$ Investasi, $\mathrm{X}_{2}$ Tenaga Kerja terhadap variabel dependen Y PDRB Kabupaten Kutai Timur sebesar $65,9 \%$.

Hasil analisis menunjukkan bahwa variabel tenaga kerja berpengaruh positif dan tidak signifikan terhadap PDRB Kabupaten Kutai Timur. Dapat di simpulkan bahwa setiap kenaikan $1 \%$ tenaga berdampak besar tehadap PDRB Kabupaten Kutai Timur.

Tenaga kerja dan PDRB terletak pada kenyataan bahwa tenaga kerja adalah kendaraan yang mendorong pembangunan ekonomi. Pembangunan yang akan mengarah pada pertumbuhan ekonomi hanya dapat dimulai dan dilaksanakan oleh komponen manusia dalam perekonomian apapun karena perekonomian tidak dapat membangun dirinya dalam arti yang abstrak. Ini hubungan antara tenaga kerja dan pembangunan ekonomi merupakan salah satu alasan komponen manusia dalam perekonomian setiap memiliki dampak langsung pada tingkat pembangunan ekonomi di wilayah itu. 


\section{SIMPULAN}

Berdasarkan hasil analisis dan pembahasan yang telah dikemukakan pada bab 4 dapat disajikan beberapa kesimpulan seperti berikut:

1. variabel Investasi secara simultan berpengaruh positif dan signifikan terhadap PDRB Kabupaten Kutai Timur. terbukti dengan uji F pada signifikansi lebih kecil dari 0,05 (alpha) maka hipotesis pertama diterima.

2. Secara partial variabel tenaga kerja berpengaruh positif tetapi tidak signifikan terhadap PDRB, terbukti dari uji t dengan nilai signifikansi $>0,05$ yang menyimpulkan tenaga kerja berpengaruh tidak signifikan terhadap PDRB, sehingga hipotesis kedua ditolak.

\section{SARAN}

Berdasarkan hasil analisis dan pembahasan serta kesimpulan tersebut dapat disajikan beberapa saran seperti berikut:

Melihat besarnya pengaruh investasi terhadap PDRB, maka investasi pemerintah diharapkan dapat dimaksimalkan dan disarankan agar pengeluaran investasi hendaknya ditujukan ke arah pembangunan yang akan mempengaruhi kelancaran kegiatan perekonomian, ketika sarana dan pra sarana dikelola dengan baik, pastinya akan menarik investor investor yang akan menannamkan modalnya di Kabupaten Kutai Timur sehingga akan ada lapangan lapangan kerja yang akan membantu meningkatkan perkonomian.

\section{DAFTAR PUSTAKA}

Anonim, 2010. PDRB Menurut Lapangan Usaha Di Kabupaten Kutai Timur Tahun 2009.2010. BPS Kabupaten Kutai Timur, Sangata.

Anonim, 2013. PDRB Menurut Lapangan Usaha Di Kabupaten Kutai Timur Tahun 2012-2013, BPS Kabupaten Kutai Timur, Sangata.

Anonim, 2013. Kutim Dalam Angka Setiap Terbitan, BPS Kalimantan Timur, Sangata.

Arsyad, Lincoln. 1999. Ekonomi Pembangunan, Edisi Keempat, Penerbit STIE YKPN, Yogyakarta.

Alkadri, 1999. Sumber-Sumber Pertumbuhan Ekonomi Indonesia, Jurnal Pusat Studi Indonesia, Universitas Terbuka.

Basuki, 1997. Kajian Mengenai Pengaruh Penanaman Modal Asing Langsung Terhadap Pertumbuhan Ekonomi dan Tabungan Domestik Indonesia Tahun 1969-1994. Jurnal Ekonomi dan Bisnis Indonesia Vol.12,2,50-65, Universitas Gajah Mada, Yogyakarta.

Gujarati, Damodar, 1995. Basic Econometrics, Third Edition. McGraw Hill International Editions, New York.

Gunadi, Brata, Aloysius, 2004. Analisis Hubungan Imbal Balik Antara Pembangunan Manusia dan Kinerja Ekonomi Daerah Tk.II di Indonesia. Lembaga Penelitian Universitas Atma Jaya, Yogyakarta.

Kuncoro, Mudrajat. 1997. Ekonomi Pembangunan: Teori, Masalah dan Kebijakan. UPP AMP YKPN Yogyakarta.

Mankiw, N. Gregory, 2000. Teori Makro Ekonomi. Ed.4, Penerbit Erlangga, Jakarta.

Pancawati, Neni, 2000. Pengaruh Rasio Kapital-Tenaga Kerja, Tingkat Pendidikan, Stok Kapital dan Pertumbuhan Penduduk Terhadap Tingkat Pertumbuhan GDP Indonesia, Jurnal Ekonomi dan Bisnis Indonesia Vol.15, No.02, Universitas Gajah Mada, Yogyakarta

Ranis, Gustav. et. al. 2000. Economic Growth and Human Development. World Development, Vol.28, No.2, pp.197-219, 2000.

Sumodiningrat, Gunawan, 2002. Pengantar Ekonometrika. Penerbit BPFE-UGM, Yogyakarta. 
Yuliarmi, Nyoman. 2008. Pengaruh Konsumsi Rumah Tangga, Investasi dan Pengeluaran Pemerintah Terhadap PDRB Propinsi Bali; Bulletin Studi Ekonomi Vo.13 No.2 Tahun 2008, Universitas Udayana Denpasar.

Sukirno, Sadono.2000 Makroekonomi Modern: Perkembangan Pemikiran Dari Klasik Hingga Keynesian Baru. Raja Grafindo Pustaka

Suryana, 2000. Ekonomi Pembangunan: Problematika dan Pendekatan. Penerbit Salemba Empat Edisi Pertama, 2000.

Susanti, Hera, Moh.Ihsan dan Widyanti. 1995. Indikator-Indikator Makroekonomi, Jakarta, LPEMFE-UI

Tarigan, Robins. 2005, Ekonomi Regional teori dan aplikasi. Penerbit Bumi Aksara, Jakarta

Todaro, Michael. 2004. Pembangunan Ekonomi di Dunia Ketiga. Penerbit Erlangga Edisi Kedelapan, 2004

Wibisono, Yusuf. 2005. Sumber-Sumber Pertumbuhan Ekonomi Regional: Studi Empiris Antar Propinsi di Indonesia, 1984-2000. Jurnal Ekonomi dan Bisnis Indonesia Vol.02, Universitas Gajah Mada, 2005 